\title{
Abstracts najaarsvergadering NVU, 3 november 2017, Nieuwegein
}

\section{Kwantitatieve bepaling van fasciesparing verbetert de voorspelling van membraneuze urethrale lengte en binnenste levator afstand op incontinentie na robotgeassisteerde radicale prostatectomie}

R.C.V. van der Roest, N. Grivas, E. Wit, D.K. Schouten,

F. Cavicchioli, C.N. Tillier, A. Bex, I.G. Schoots, W. Artibani, S.W.T.P.J. Heijmink en H.G. van der Poel

Antoni van Leeuwenhoek, Amsterdam

\section{Introductie}

De studie had tot doel om te bepalen of preoperatieve anatomische structuren van prostaat en kleine bekken, en intraoperatieve fascie preservatie (FP), herstel van continentie voorspellen na robotgeassisteerde laparoscopische prostatectomie (RARP).

\section{Materiaal en methoden}

Tussen januari 2012 en maart 2016 werden 439 patiënten met prostaatkanker $(\mathrm{PCa})$, met normale preoperatieve continentie, retrospectief geïncludeerd. Negen anatomische bekkenbodemstructuren werden gemeten op preoperatieve endorectale Magnetic Resonance Imaging. De International Consultation on Incontinence Questionnaire-Short Form (ICIQ-SF) werd gebruikt om urine-incontinentie (UI) te bepalen. UI was gedefinieerd als ieder ongewild urineverlies of luiergebruik. FP-score werd gedefinieerd als de mate van FP van basis tot apex van de prostaat; dit werd peroperatief bepaald door de uroloog. Cox-analyse werd verricht om voorspellende factoren te bepalen voor vroeg postoperatief herstel van continentie. Binaire logistische regressie werd uitgevoerd om een risicocalculator te ontwikkelen.

$\bar{\square}$ dr. Henk G. van der Poel

h.vd.poel@nki.nl

Tijdschrift voor Urologie,

Bohn Stafleu van Loghum, Houten, Nederland

\section{Resultaten}

Bij mediane follow-up (12,1 maanden) had 50,8\% UI. Grotere membraneuze urethrale lengte (MUL; $p<0,0001$; OR 1,309; CI 1,211, 1,415) en kleinere binnenste levator afstand (ILD; $p<0,0001 ; \mathrm{OR}=0,904 ; 95 \%$-BI $=0,85-0,961)$ waren voorspellers van vroeg herstel van continentie volgens de cox multivariate analyse. In de multivariate binaire logistische regressieanalyse waren grotere MUL $(p<0,0001$; OR $=1,565$; $95 \%-\mathrm{BI}=1,362-1,798)$, kortere $\mathrm{ILD}(p<0,0001 ; \mathrm{OR}=0,819$; $\mathrm{B} 95 \%$-BI $=0,742-0,904)$ en hogere FP-score $(p=0,024$; $\mathrm{OR}=1,089 ; 95 \%-\mathrm{BI}=1,011-1,172)$ onafhankelijke voorspellers voor continentie. De risicocalculator voorspelde herstel van continentie tussen $1,3 \%$ en $99 \%$. Zie figuur 1.1 .

\section{Conclusie}

Naast mate van FP, voorspellen preoperatief grotere MUL en kortere ILD op een MRI-scan de kans op herstel van continentie na RARP. De risicocalculator kan worden gebruikt om patiënten met hoog risico op UI te identificeren.

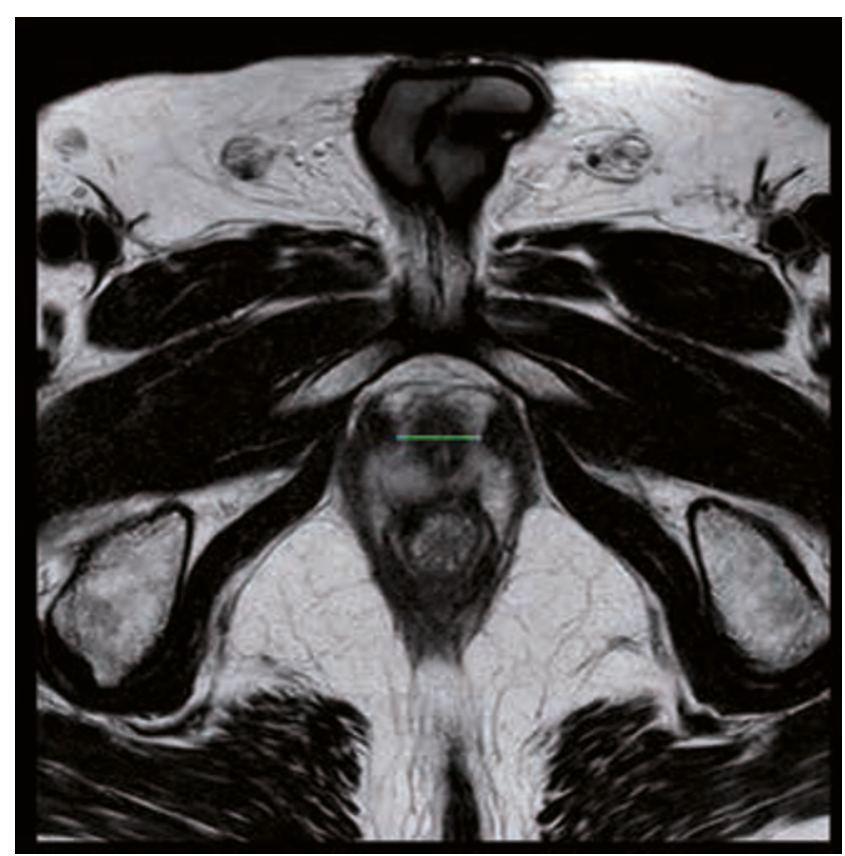

Figuur 1.1 Binnenste levator afstand (ILD). 


\section{Schildwachtklierprocedure bij klinisch stadium- I-testistumor}

J.M. Blok, J.M. Kerst, E. Vegt, R.P. Meijer, J.L.H.R. Bosch, A. Bex, H.G. van der Poel en S. Horenblas

Antoni van Leeuwenhoek, Amsterdam; Universitair Medisch Centrum Utrecht, Utrecht

\section{Introductie}

Ongeveer 20-30\% van de patiënten met een kiemceltumor in klinisch stadium I hebben occulte metastasen in de retroperitoneale lymfeklieren ten tijde van presentatie en krijgen gedurende active surveillance een recidief. Met een schildwachtklierprocedure is het mogelijk om deze patiënten in een vroeg stadium te identificeren. Wij rapporteren de langetermijnresultaten van deze aanpak.

\section{Materiaal en methoden}

Tussen 2001 en 2015 zijn 27 patiënten met een verdenking op een kiemceltumor in klinisch stadium I geïncludeerd. De schildwachtklier werd geïdentificeerd door middel van SPECT/CT en/of lymfoscintigrafie. In dezelfde operatiesessie als de inguïnale orchidectomie werd de schildwachtklier laparoscopisch gereseceerd. Patiënten met een schildwachtklier positief voor metastase werden behandeld met adjuvante chemotherapie. Eén patiënt met een negatieve schildwachtklier werd op eigen verzoek behandeld met één kuur carboplatin.

\section{Resultaten}

Van de 27 geïncludeerde patiënten werd bij twee patiënten geen schildwachtklier gevisualiseerd bij scintigrafie. Bij de overige 25 patiënten werd een mediaan aantal van drie schildwachtklieren (range 1-4) per patiënt gereseceerd. Bij twee patiënten werd bij histopathologisch onderzoek geen maligniteit in de testis gevonden. Van de overige 23 patiënten met een kiemceltumor hadden $3 / 23$ (13,0\%) occulte metastasen in de schildwachtklier. Na een mediane followup van 62,2 maanden (range 22,3-143,4) waren alle 23 patiënten tumorvrij.

\section{Conclusie}

De schildwachtklierprocedure maakt vroege identificatie van patiënten met een klinisch stadium-I-kiemceltumor met occulte lymfekliermetastasen mogelijk.

\section{De invloed van de tracerinjectie op de detectie van lymfekliermetastasen bij prostaatcarcinoom tijdens robotgeassisteerde radicale prostatectomie met sentinel node procedure}

G.H. KleinJan, E.M. Wit, M. Donswijk, F.W.B. van Leeuwen en H.G. van der Poel
Antoni van Leeuwenhoek, Amsterdam; Leids Universitair Medisch Centrum, Leiden, Canisius-Wilhelmina Ziekenhuis, Nijmegen

\section{Introductie}

Een robotgeassisteerde radicale prostatectomie (RARP) en sentinel node (SN) procedure gecombineerd met bekkenklierdissectie is een behandelmodaliteit voor het intermediair en hoogrisicoprostaatcarcinoom (PCa). Een eerdere studie heeft laten zien dat de injectietechniek van invloed is op locatie en aantal gevonden SNs (Buckle et al., JNM 2012). In deze prospectieve gerandomiseerde fase-II-studie werd gekeken naar het verschil in detectie van lymfeklier (LK) metastasen bij een intratumorale (IT) vs. intraprostatische (IP) injectietechniek.

\section{Materiaal en methoden}

PCa-patiënten behandeld met RARP $(n=113)$ met $>5 \%$ risico op LK-metastasen volgens het Briganti-nomogram werden geïncludeerd. Patiënten werden gerandomiseerd voor een injectie van hybride tracer (ICG-99mTc-nanocolloid) in twee depots van $1 \mathrm{ml}$ gericht op de tumor $(n=55$; IT-groep) versus vier depots van $0,5 \mathrm{ml}$ in de perifere zone van de prostaat ( $n=58$; IP-groep). De locatie van SNs werd preoperatief bepaald met lymfoscintigram en SPECT/CT. Met intraoperatieve radio- en fluorescentiegeleide technieken werden SNs gelokaliseerd en verwijderd, gevolgd door een bekkenklierdissectie. Gekeken werd naar het aantal verwijderde SNs en percentage metastasen in de SNs in beide groepen.

\section{Resultaten}

De twee groepen (IT vs. IP) waren vergelijkbaar voor tumorkarakteristieken, Briganti-score (13,5 vs. 10,8; $p=0,117)$, aantal SNs op SPECT/CT (3,0 vs. 4,0; $\mathrm{p}=0,489)$ en aantal gereseceerde SNs $(3,5 v s .4,0 ; p=0,128)$. Een unilaterale $(12 v s .6 ; p=0,0001)$ en bilaterale $(3 v s .1 ; p=0,032)$ non-visualisatie werd significant meer gevonden in de ITgroep. Twee patiënten in de IT-groep hadden een fout-negatieve procedure. Het aantal pN1-patiënten was significant hoger in de IT-groep (23 vs. 14; $p=0,045)$. Op klierniveau was het aantal verwijderde SNs in de IT-groep lager (286 vs. $368 ; p=0,317$ ) en het aantal positieve SNs vergelijkbaar (28 vs. $22 ; p=0,571$ ), terwijl het aantal positieve non-SNs tussen beide groepen significant verschilde (10 vs. 36; $p=0,010)$.

\section{Conclusie}

Met IT-tracertoediening werden meer pN1-patiënten geidentificeerd, terwijl het aantal positieve non-SNs afnam. 


\section{4. 'Off-protocol'-selectie van prostaatkanker- patiënten voor active surveillance geeft een slechtere prognose}

T.F.W. Soeterik, H.H.E. van Melick, L.M. Dijksman, J.A. Witjes, D.H. Biesma en J.P.A. van Basten

St. Antonius Ziekenhuis, Nieuwegein; Radboud Universitair Medisch Centrum, Nijmegen; Canisius-Wilhelmina Ziekenhuis, Nijmegen

\section{Introductie}

Active surveillance (AS) is in onderzoekssetting een zeer veilige strategie gebleken bij patiënten die waren geselecteerd volgens de strikte PRIAS-criteria. In de dagelijkse praktijk is de patiëntselectie mogelijk minder nauwgezet en wordt AS ook aangeboden aan patiënten die niet exact aan deze criteria voldoen. Het is onvoldoende bekend of zogenoemde 'off-protocol'-selectie voor AS is geassocieerd met een slechtere prognose.

\section{Materiaal en methoden}

Prostaatkankerpatiënten, gediagnosticeerd tussen 2008 en 2015, primair behandeld met AS in vijf Nederlandse opleidingsziekenhuizen, werden retrospectief geëvalueerd. Er werd onderzocht welk percentage van de patiënten onder AS niet voldeden aan een of meer van de PRIAS-inclusiecriteria ( $\leq$ cT2; PSA $\leq 10$; PSA-densiteit $\leq 0,20$; Gleason-score $\leq 6$ en aantal positieve biopten $\leq 2$ ). Tevens werd onderzocht of deze patiënten een hogere kans hadden op een slechtere PA na radicale prostatectomie (pT-stadium $\geq \mathrm{T} 3 \mathrm{en} /$ of Gleason-score $\geq 8$; positief snijvlak) en het optreden van metastasen.

\section{Resultaten}

In totaal voldeden 433/973 (45\%) van de AS-patiënten niet aan een of meer PRIAS-selectiecriteria, en 159/973 (16\%) voldeden niet aan twee of meer criteria. In totaal ondergingen 359 patiënten radicale behandeling na beëindigen van active surveillance. Hiervan ondergingen 148/359 (41\%) een radicale prostatectomie. Patiënten die niet voldeden aan een of meer selectiecriteria hadden een significant hogere kans op pT-stadium $\geq \mathrm{T} 3$ en/of Gleason-score $\geq 8(31 / 76$ (41\%) vs. 13/70 (19\%); $p=0,003)$ en positieve snijvlakken (31/73 (42\%) vs. 16/70 (23\%); $p=0,013)$, vergeleken met patiënten die wel voldeden aan alle PRIAS-inclusiecriteria. Het percentage patiënten dat in de follow-up metastasen ontwikkelde, was significant hoger onder de mannen die niet voldeden aan twee of meer selectiecriteria, dan onder de mannen die niet voldeden aan maximaal één PRIASselectiecriterium (9/159 (6\%) vs. 13/814 (2\%); $p=0,002)$.

\section{Conclusie}

Een substantieel percentage patiënten met prostaatkanker onder AS voldoet niet aan één of meer van de PRIAS- inclusiecriteria. Deze patiëntengroep heeft een slechtere prognose.

\section{Positief snijvlak bij RARP: geen goede kwaliteitsparameter voor chirurgische techniek per se?}

\author{
J.A. Nieuwenhuijzen, J.P. van der Voorn, R.J.A. van Moorselaar \\ en A.N. Vis \\ VU Medisch Centrum, Amsterdam
}

\section{Introductie}

Een positief chirurgisch snijvlak (R1) wordt vaak beschouwd als kwaliteitsparameter bij robotgeassisteerde radicale prostatectomie (RARP), maar heeft vaker niet dan wel een PSA-recidief tot gevolg. In bijvoorbeeld het Martini Ziekenhuis in Hamburg worden peroperatief systematisch vriescoupes genomen en zo nodig worden extra marges weggenomen. Er worden na deze aanpassing minder positieve snijvlakken beschreven. Wij hebben onderzocht of het aanleveren van separate snijranden het percentage R1 beïnvloedt.

\section{Patiënten en methoden}

Vanaf november $2016 \mathrm{t} / \mathrm{m}$ januari 2017 werd bij alle patiënten na RARP periprostatisch weefsel afgenomen aan de lichaamszijde ter plekke van de apex, en beiderzijds laterodorsaal ter plekke van de neurovasculaire bundel/pedikel (figuur 5.1). De prostaat werd histologisch beoordeeld op gebruikelijke wijze, onder andere op een positief chirurgisch snijvlak. Wanneer bij een patiënt met een positief chirurgisch snijvlak het periprostatisch weefsel negatief was bij histologisch onderzoek, werd het snijvlak herbeoordeeld als negatief chirurgisch snijvlak (R0).

\section{Resultaten}

In de periode januari $2015 \mathrm{t} / \mathrm{m}$ september 2016 was het chirurgisch snijvlak na RARP positief in 53/171 (30,1\%) van de patiënten (groep 1). Na het systematisch histologisch beoordelen van de andere locaties in de periode november $2016 \mathrm{t} / \mathrm{m}$ januari 2017 daalde het percentage positieve snijvlakken naar 3/42 (7,1\%) (groep 2). PSA-recidiefpercentage na een mediane follow-up van 13 maanden en 6 maanden was $23 / 171(13,5 \%)$ en $3 / 42(7,1 \%)$, in groep 1 en 2 respectievelijk.

\section{Conclusie}

$\mathrm{Na}$ aanpassen van de histologische beoordeling van de prostaat door separate beoordeling van periprostatische snijvlakken daalde het percentage R1 van $30,1 \%$ naar $7,1 \%$, terwijl de chirurgische ingreep op dezelfde manier plaatsvond. Het percentage positief chirurgisch snijvlak lijkt kunstmatig 


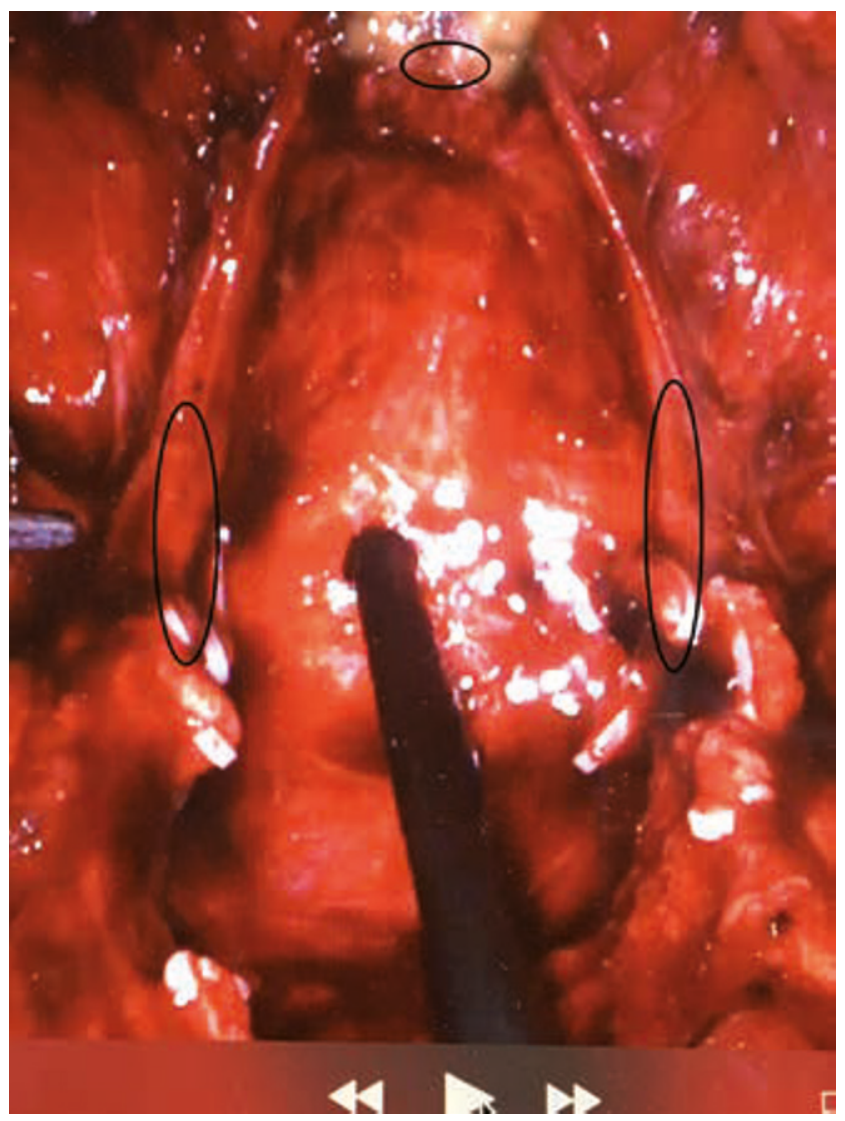

Figuur 5.1 Status na robotgeassisteerde laparoscopische radicale prostatectomie (RARP). Cirkels geven de gebieden aan waar weefselfragmenten zijn afgenomen als snijvlak voor histologisch onderzoek.

omlaag te brengen. Positief snijvlak als kwaliteitsparameter staat daarmee ter discussie, zolang er geen consensus is over de histologische beoordeling van het PA-preparaat.

\section{Externe validatie van predictiemodellen die uitzaaiing in de lymfeklieren voorspellen bij patiënten gediagnosticeerd met prostaatkanker in Nederland}

T.A. Hueting, E.B. Cornel, R.A. Korthorst, R.G. Pleijhuis, H. Jansen, D.M. Somford, J.P.A. van Basten, J.A.M. van der Palen en H. Koffijberg

Evidencio, Haaksbergen; Ziekenhuis Groep Twente, Almelo/ Hengelo; Medisch Spectrum Twente, Enschede; Canisius Wilhelmina Ziekenhuis, Nijmegen; ProZIB, Nijmegen; Universiteit Twente, Enschede

\section{Introductie}

Er zijn verschillende predictiemodellen die het risico op lymfekliermetastasen bij prostaatkanker voorspellen. De meest gebruikte predictiemodellen zijn het Briganti- en MS-
KCC-nomogram, de Partin-tables en de Roach-formule. Het doel van deze studie was om alle beschikbare predictiemodellen te valideren in een Nederlands cohort van prostaatkankerpatiënten die een lymfeklierdissectie hebben ondergaan.

\section{Materiaal en methoden}

16 predictiemodellen zijn gevalideerd met data van 1028 patiënten die tussen oktober 2008 en mei 2017 pelviene lymfeklierdissectie ondergingen, waarbij ten minste 10 klieren werden verwijderd. De ProZIB-database is gebruikt en aangevuld met patiënten uit twee grote opleidingsklinieken. De volgende parameters werden geëvalueerd: prostaatspecifiek antigeen (PSA), klinisch tumorstadium (cT), Gleasonscore bij biopsie, totaal aantal genomen (inclusief antal positieve) biopten en het aantal verwijderde lymfeklieren. Alle predictiemodellen zijn gevalideerd met hun oorspronkelijke coëfficiënten en zijn geëvalueerd met de receiving operating characteristic (ROC) curve.

\section{Resultaten}

Positieve lymfeklieren waren aanwezig bij 281 (27\%) patiënten. Bij vergelijking van patiënten met en zonder positieve lymfeklieren werden significante verschillen $(p<$ $0,05)$ gevonden in PSA-waarde, cT-stadium, Gleason-score, aantal positieve biopten en aantal verwijderde lymfeklieren. Van de genoemde vier, meest gangbare, predictiemodellen, lieten de meest recente updates de grootste oppervlaktes onder de ROC-curve zien. Voorspellingen die werden berekend met het Briganti-nomogram uit $2012(0,76)$ en het MSKCC-nomogram $(0,74)$ bleken het meest accuraat.

\section{Conclusie}

De beschikbare predictiemodellen die het risico op lymfekliermetastasen voorspellen, zijn gevalideerd voor een $\mathrm{Ne}-$ derlands cohort prostaatkankerpatiënten die een adequate lymfeklierdissectie hebben ondergaan. Uit analyse van 16 predictiemodellen is het Briganti-nomogram het meest accurate predictiemodel gebleken voor Nederlandse mannen met prostaatkanker. Het percentage positieve biopten was de sterkste voorspeller in dit model.

\section{Vroege oncologische uitkomsten van $68 \mathrm{Ga}$ - PSMA PET/CT gestuurde salvagetherapie bij mannen met biochemisch recidief na radicale prostatectomie}

P.J. van Leeuwen, L. Emmett, M. Donswijk, P.D. Stricker, F.J. Pos, E.M.K. Wit en H.G. van der Poel

Antoni van Leeuwenhoek, Amsterdam 


\section{Introductie}

Salvageradiotherapie (SRT) is een behandelingsoptie voor prostaatkanker (PC) patiënten met een biochemisch recidief (BCR) na radicale prostatectomie (RP). 68Ga-PSMA-PET/ $\mathrm{CT}$ maakt het mogelijk recidief-PC te diagnosticeren bij een lage PSA-waarde. Deze studie toont vroege oncologische uitkomsten van een serie 68Ga-PSMA-PET/CT gestuurde salvagetherapie (ST) bij mannen met BCR na RP.

\section{Materiaal en methoden}

Totaal 113 patiënten met PSA-stijging $(0,2-1,0 \mathrm{ng} / \mathrm{ml})$ na RP ondergingen een 68Ga-PSMA-PET/CT. Verzameld werden de patiëntgegevens en tumorkarakteristieken, 68GaPSMA-PET/CT-resultaten, type ST en de PSA-respons na ST. De PSA-respons was gedefinieerd als PSA $\leq 0,01$ of een $>75 \%$ - reductie in de laatstgemeten PSA na ST. Patiënten bij wie ST werd gecombineerd met hormonale therapie (HT) werden geëxcludeerd van PSA-responsanalyse.

\section{Resultaten}

De mediane (IQR) leeftijd van de patiënt, PSA tijdens PET/ CT en tijd na RP was 68 (62-71) jaar, 0,32 (0,24-0,50) ng/ml en 36 (13-74) maanden, respectievelijk. 68Ga-PSMA-PET/ CT was positief bij 78 (69\%) mannen, van wie $32(28 \%)$ mannen positief waren in de prostaatfossa, $30(26 \%)$ in de pelviene lymfeklieren $+/$ - prostaatfossa en $16(14 \%)$ een metastase op afstand +/- lymfeklieren + - prostaatfossa hadden. 20 mannen kregen HT en werden geëxcludeerd van de PSA-responsanalyse. 67 (72\%) mannen ondergingen ST met een mediane follow-up van 12,5 maanden. In totaal werd een PSA-respons vastgesteld bij 47 (71\%) mannen. 17 mannen hadden een negatieve PET/CT en ondergingen SRT van de prostaatfossa. De PSA-respons na SRT werd vastgesteld bij 14 (82\%) mannen, terwijl de PSA-progressie werd vastgesteld bij 16 van de 20 mannen met een negatieve PET/CT bij wie geen SRT werd uitgevoerd. 30 mannen hadden een positieve PET/CT alleen in de prostaatfossa en kregen SRT van de prostaatfossa; PSA-respons bij 25 (83\%) mannen. 16 mannen hadden een positieve PET/CT in de pelviene lymfeklieren $+/$ - de prostaatfossa en kregen SRT en/of salvagechirurgie van de pelviene lymfeklieren; PSArespons bij $8(50 \%)$ mannen. In multivariate logistische regressieanalyse waren PSA en het resultaat van de PET/CT significant gecorreleerd met PSA-respons.

\section{Conclusie}

68Ga-PSMA PET/CT identificeert mannen met BCR na RP die relatief beter reageren op SRT van de prostaatfossa. Zodoende kan 68Ga-PSMA PET/CT gebruikt worden om patiënten beter te selecteren en te informeren voor ST.

\section{Gradering van het niet-spierinvasieve blaas- carcinoom (NMIBC) volgens de WHO1973 versus de WHO2004: reproduceerbaarheid en prognos- tische waarde door drie uropathologen in een multicenter setting}

J. Bosschieter, A. Hentschel, C.D. Savci-Heijink, J.P. van der Voorn, L. Rozendaal, A.N. Vis, B.I. Lissenberg-Witte, R.J.A. van Moorselaar en J.A. Nieuwenhuijzen

VU Medisch Centrum, Amsterdam

\section{Introductie}

Gradering van NMIBC is belangrijk voor het voorspellen van progressie en gaat gepaard met behandelconsequenties. In 1973 heeft de WHO een classificatie ontwikkeld. Vanwege matige reproduceerbaarheid van deze classificatie is er een nieuw systeem ontwikkeld: de WHO2004. De superioriteit van dit systeem is echter nog niet aangetoond. In deze studie vergelijken wij de reproduceerbaarheid evenals de prognostische waarde van de WHO1973- en WHO2004gradering.

\section{Materiaal en methoden}

328 preparaten van 232 patiënten die een transurethrale resectie ondergingen, zijn geblindeerd beoordeeld door drie pathologen uit twee verschillende centra volgens de WHO1973- en WHO2004-classificatie. Reproduceerbaarheid werd geanalyseerd middels Fleiss' $\kappa$ en overeenstemmingspercentages. Progressie was gedefinieerd als spierinvasie of metastasen. Tijd tot progressie werd geanalyseerd met Cox-regressie waarbij gecorrigeerd werd voor bekende voorspellers.

\section{Resultaten}

Overeenkomst in gradering werd gevonden in $32 \%$ van de gevallen $(\kappa=0,26$; 95\%-BI $=0,19-0,24)$ voor de WHO73classificatie en in $52 \%$ van de gevallen $(\kappa=0,39$; $95 \%$ $\mathrm{BI}=0,30-0,36)$ voor de WHO2004-classificatie. Na een mediane follow-up van 60 maanden trad bij 33 patiënten progressie op. De univariabele en multivariabele analyse voor het voorspellen van progressie is per graderingsclassificatie en patholoog (A-C) weergegeven in tabel 8.1.

\section{Conclusie}

Gradering is subjectief. Uit onze data blijkt dat de WHO2004-classificatie beter reproduceerbaar is dan de WHO1973-classificatie. Beide zijn echter slecht reproduceerbaar. Welk classificatiesysteem het best progressie voorspelt in onze dataset, verschilt per patholoog. 
Tabel 8.1 Aantal patiënten per graderingscategorie en percentage patiënten met progressie per graderingscategorie, evenals de voorspellende waarde van gradering van NMIBC $(n=232)$ volgens de WHO1973- en de WHO2004-classificatie voor de tijd tot progressie, door drie uropathologen in een multicenter setting.

\begin{tabular}{|c|c|c|c|c|c|}
\hline \multicolumn{6}{|l|}{ WHO1973 } \\
\hline & $\mathrm{G} 1, n(\%)$ & $\mathrm{G} 2, n(\%)$ & $\mathrm{G} 3, n(\%)$ & hazard ratio $(95 \%-\mathrm{BI})$ & $p$-waarde $(\mathrm{U} / \mathrm{M})$ \\
\hline patholoog A & $1 / 48(2,1)$ & $12 / 102(12)$ & $20 / 82(24)$ & $1,90(0,86-3,98)$ & $<0,001 / 0,12$ \\
\hline patholoog B & $3 / 17(18)$ & $6 / 103(5,8)$ & $24 / 112(21)$ & $2,01(0,89-4,55)$ & $0,001 / 0,09$ \\
\hline patholoog C & $2 / 53(3,8)$ & $18 / 142(13)$ & $13 / 37(35)$ & $2,40(1,12-5,15)$ & $<0,001 / 0,02$ \\
\hline \multicolumn{6}{|l|}{ WHO2004 } \\
\hline & $\mathrm{LG}, n(\%)$ & & $\mathrm{HG}, n(\%)$ & hazard ratio $(95 \%-\mathrm{BI})$ & $p$-waarde $(\mathrm{U} / \mathrm{M})$ \\
\hline patholoog A & $8 / 119(6,7)$ & & $25 / 113(22)$ & $2,13(0,89-5,13)$ & $<0,001 / 0,09$ \\
\hline patholoog B & $7 / 58(12)$ & & $26 / 174(15)$ & $0,88(0,37-2,10)$ & $0,4 / 0,8$ \\
\hline patholoog C & $8 / 140(5,7)$ & & $25 / 92(27)$ & $3,51(1,41-8,74)$ & $<0,001 / 0,007$ \\
\hline
\end{tabular}

$\mathrm{WHO}=$ World Health Organization grading system; G1 = $\operatorname{graad} 1 ; \mathrm{G} 2=\operatorname{graad} 2 ; \mathrm{G} 3=\operatorname{graad} 3 ; \mathrm{LG}=$ laaggradig; $\mathrm{HG}=$ hooggradig; $\mathrm{U}=$ univariaat; $\mathrm{M}=$ multivariaat.

\section{De artificiële sfincterprothese bij vrouwen met recidief of neurogeen bepaalde stress urine- incontinentie}

F. Valk

MaastrichtUMC+, Maastricht

\section{Introductie}

Stressincontinentie is invaliderend, vooral wanneer door de dokter of de patiënt na een of meerdere ingrepen de situatie geaccepteerd wordt, omdat vervolgtherapie te invasief of risicovol wordt geacht. De sfincterprothese bij vrouwen is daarom lange tijd in Nederland vrijwel niet toegepast. Doel van deze studie is het meten van functionele uitkomsten, patiënttevredenheid en kwaliteit van leven na sfincterprothese plaatsing bij vrouwelijke patiënten.

\section{Materiaal en methoden}

Er werd een retrospectieve studie verricht naar implantaties van sfincterprotheses tussen 2011 en 2017 die door één uroloog waren geplaatst in één ziekenhuis. Geïncludeerd werden patiënten met urine-incontinentie, met meer dan één incontinentie-ingreep voorafgaand aan de sphincterprothese of neurogeen bepaalde urine-incontinentie. De postoperatieve incontinentie werd gekwantificeerd met de hoeveelheid pads per dag. Naast patiënttevredenheid werd de postoperatieve symptoomhinder (Urogenital Distress Inventory (UDI) 6) en kwaliteit van leven (Incontinence Impact Questionnaire (IIQ) 7) gemeten.

\section{Resultaten}

In totaal werden 15 implantaties bij 13 vrouwelijke patiënten (gemiddelde leeftijd 64,5 jaar) verricht (2 patiënten ondergingen een cuff-revisie). Bij twee patiënten (na TVT-blaas-
Tabel 9.1 Patiëntkarakteristieken en uitkomsten van de 13 vrouwelijke patiënten.

\begin{tabular}{ll}
\hline patiëntkarakteristieken & \\
\hline leeftijd (jaren), gem. (SD) & $64,5(5,9)$ \\
\hline $\begin{array}{l}\text { tijd van start incontinentie tot implantatie (jaren), } \\
\text { gem. (SD) }\end{array}$ & $13,9(11,4)$ \\
\hline follow-up: prothesetijd in situ (jaren), gem. (SD) & $3,5(1,7)$ \\
\hline voorgeschiedenis & $6(46 \%)$ \\
\hline uterusextirpatie (\%) & \\
\hline totaal eerdere incontinentie-ingrepen (\%) & $1(8 \%)^{*}$ \\
0 & $3(23 \%)$ \\
1 & $6(46 \%)$ \\
2 & $1(8 \%)$ \\
3 & $2(15 \%)$ \\
\hline 4 & $14,5(16,9)$ \\
\hline uitkomsten & $2,2(5,7)$ \\
\hline UDI-6 totaal (score 0-100), gem. (SD) & \\
\hline IIQ-7 totaal (score 0-100), gem. (SD) & $1(8 \%)$ \\
\hline patiënttevredenheid (\%) & $0(0 \%)$ \\
\hline neutraal & $2(15 \%)$ \\
matig tevreden & $10(77 \%)$ \\
tevreden & $13(100 \%)$ \\
\hline zeer tevreden & $13(100 \%)$ \\
\hline zelfstandige sfincterbediening (\%) & $0,6(2,3)^{* *}$ \\
\hline aanraden aan patiënt met gelijkaardige klachten $(\%)$ & $10(77 \%)$ \\
\hline voor implantatie, gem. (SD) & \\
\hline na implantatie, gem. (SD) & \\
\hline continent na implantatie (0 pads) (\%) & \\
\hline
\end{tabular}

UDI $=$ Urogenital Distress Inventory; IIQ = Incontinence Impact Questionnaire.

* 1 patiënt had primaire neurogene sfincterdeficiëntie.

** Verschil pads voor/na: $p=<0,001$. 
halserosie en na pelvien lipoom) werd de prothese geplaatst in twee tempi met omentumflap, bij een van deze patiënten werd de prothese succesvol geplaatst. Alle patiënten met een succesvolle protheseplaatsing werden geïncludeerd. Negen patiënten $(69 \%)$ hadden voorafgaand aan de plaatsing twee of meer incontinentie-ingrepen ondergaan. Het gemiddeld aantal pads per dag daalde van zes preoperatief naar 0,9 postoperatief $(p<0,001)$. Acht patiënten $(62 \%)$ hadden postoperatief geen pad meer nodig. Gemiddelde UDI-6score was 14,5 en de IIQ-7-score was 2,2. Tien patiënten (77\%) waren zeer tevreden over de behandeling. Zie tabel 9.1.

\section{Conclusie}

De artificiële sfincterprothese bij vrouwen met veelal recidief incontinentieproblematiek en een uitgebreide urologische voorgeschiedenis geeft een voor deze patiëntengroep gunstig functioneel resultaat, een goede kwaliteit van leven en een hoge patiënttevredenheid. Bij recidief incontinentie, ook na meerdere eerdere pogingen tot chirurgische correctie, moet deze optie worden overwogen.

\section{Selectie van patiënten voor zenuwsparende chi- rurgie bij robotgeassisteerde laparoscopische radi- cale prostatectomie (RARP) in Nederlandse zieken- huizen: resultaten van een multicenterstudie}

\section{R. ter Haar en A. Vis \\ VU Medisch Centrum, Amsterdam}

\section{Introductie}

Meerdere preoperatieve parameters voorspellen het risico op extracapsulaire ziekte (ECE) bij het gelokaliseerd prostaatcarcinoom. (Een bepaald risico op) ECE kan reden zijn om af te zien van zenuwsparing bij RARP. Middels een online vragenlijst onderzochten wij welke variabelen Nederlandse urologen gebruiken in de besluitvorming over het wel of niet doen van zenuwsparende chirurgie bij mannen met een indicatie voor RARP.

\section{Materiaal en methode}

Een online vragenlijst werd gestuurd naar 40 urologen binnen 26 klinieken. De vragen hadden betrekking op specifieke risicofactoren voor ECE en daarmee op de keuze voor zenuwsparing bij RARP, zoals klinische (cT2c-cT3-4), biochemische $(20 \mathrm{ng} / \mathrm{mL} \leq \mathrm{PSA} \leq 20 \mathrm{ng} / \mathrm{mL})$, pathologische (Gleason-score $4+3,4+4,4+5$ ), of radiologische variabelen (mpMRI) en combinaties hiervan (MSKCC, Partin tables).

\section{Resultaten}

Het responspercentage was hoog, $80 \%$ voor uroloog en $88 \%$ voor ziekenhuis. De resultaten staan vermeld in tabel 10.1.
Tabel 10.1 Selectie van patiënten voor zenuwsparende chirurgie bij RARP.

\begin{tabular}{ll}
\hline $\begin{array}{l}\text { contra-indicaties voor zenuwsparing zoals aangegeven } \\
\text { door de urologen }\end{array}$ & $n(\%)$ \\
\hline $\begin{array}{l}c T \text {-stadium } \\
\text { T2c }\end{array}$ & $2(6 \%)$ \\
T3 & $19(59 \%)$ \\
T4 & $4(22 \%)$ \\
\hline PSA & \\
$>20 \mathrm{ng} / \mathrm{ml}$ & $6(19 \%)$ \\
niet relevant & $26(81 \%)$ \\
\hline Gleason-score, per zijde & \\
$\geq 4+3=7$ & $5(17 \%)$ \\
$\geq 4+4=8$ & $13(43 \%)$ \\
$\geq 4+5=9$ & $12(40 \%)$ \\
\hline $\begin{array}{l}\text { Gebruikt } \text { u een } \text { nomogram voor inschatting } E C E ? \\
\text { ja (MSKCC: } n=14 ; \text { Briganti: } n=2 ; \text { Partin: } n=1)\end{array}$ & $17(55 \%)$ \\
nee & $14(45 \%)$
\end{tabular}

Gebruikt u MRI?

ja, als diagnosticum (biopteren) $20(63 \%)$

ja, bepalen tumorstadium $22(69 \%)$

enkel bij negatieve biopten $11(34 \%)$

\begin{tabular}{ll}
\hline Bekijkt/interpreteert u elke MRI zelf? & \\
ja, altijd & $17(55 \%)$ \\
ja, samen met de radioloog & $52(52 \%)$ \\
nee, ik lees alleen het verslag & $5(16 \%)$ \\
\hline
\end{tabular}

Indien MRI $\geq r T 3$-stadium, ziet $u$ dan aan betreffende

zijde altijd af van zenuwsparing?

ja $26(84 \%)$

nee $5(16 \%)$

Past $u$ het chirurgisch plan aan wat betreft zenuwsparing op basis van tumorlokalisatie op MRI?

ja $29(91 \%)$

nee $3(9 \%)$

Past $u$ het chirurgisch plan aan wat betreft zenuwsparing op basis van de ligging van de zenuwbundels op MRI?

ja $14(44 \%)$

nee $18(56 \%)$

MRI geopend op OK ten aanzien van chirurgisch plan?

ja $20(64 \%)$

nee, tenzij een lastige procedure $\quad 4(13 \%)$

nee, nooit $7(23 \%)$

Opvallende bevindingen zijn dat het afwijkend rectaal onderzoek nog steeds leidend is bij de keuze rondom zenuwsparing bij RARP, evenals hoge Gleason-score $(\geq 4+4)$ en aanwijzingen voor ECE op mpMRI. Toch lijkt de keuze voor zenuwsparende chirurgie met name afhankelijk van de inschatting van de individuele uroloog en het beleid in een ziekenhuis.

\section{Conclusie}

Tussen Nederlandse urologen die een RARP uitvoeren en tussen ziekenhuizen bestaat een grote diversiteit bij de 
selectie van mannen voor een zenuwsparende RARP. Dit is weinig opvallend omdat in deze keuze rondom zenuwsparende chirurgie, urologen niet worden gesteund door internationale publicaties en guidelines.

\section{Testisprothese na een testistumor, wordt het te allen tijde voorgelegd aan de patiënt en wat is de tevredenheid?}

\author{
T.G. Jansen, E.M. Krouwel, H. Putter, R.C.M. Pelger en \\ H.W. Elzevier \\ Leids Universitair Medisch Centrum, Leiden
}

\section{Introductie}

$\mathrm{Na}$ een orchidectomie in het kader van een testistumor kan een testisprothese (TP) worden geplaatst om esthetische dan wel psychologische redenen. Niet elke patiënt krijgt de optie voorgelegd en de tevredenheid van patiënten met een TP is wisselend. In deze studie werd nagegaan in hoeverre artsen bij patiënten met een testistumor de mogelijkheid tot een prothese bespreken. Daarnaast werd de tevredenheid van patiënten met een TP onderzocht.

\section{Materiaal en methoden}

582 patiënten, die tussen 1995 en 2015 waren gediagnosticeerd met een testistumor en primair of secundair waren behandeld in een academisch ziekenhuis, ontvingen een toestemmingsverklaring. Na toestemming werd hun een vragenlijst toegestuurd. De vragenlijst werd ontworpen door onze onderzoeksgroep en getest door leden van Stichting Zaadbalkanker.

\section{Resultaten}

Van 581 geïncludeerde patiënten hebben 204 patiënten $(35,3 \%)$ deelgenomen. Uiteindelijk werd met 152 patiënten (74,5\%) de optie TP besproken; bij 113 patiënten $(55,4 \%)$ was dat voorafgaand aan de orchidectomie. Patiënten met wie TP werd besproken, waren gemiddeld jonger ten tijde van de diagnose (33,1 jaar) dan patiënten met wie dit niet werd besproken ( 36,2 jaar; $p=0,035)$. In $84 \%$ van de gevallen werd de TP aangedragen door de uroloog. Een kwart van de patiënten $(n=36 ; 23,7 \%)$ met wie TP werd besproken, gaf aan te weinig informatie te hebben ontvangen om een keuze voor een prothese te maken. In totaal kozen 28 patiënten $(13,7 \%)$ voor een prothese, van wie $75 \%$ achteraf tevreden tot zeer tevreden was. Ontevreden patiënten (14\%) rapporteerden het formaat, de textuur en het ongemak in het scrotum als nadeel. Van de 159 patiënten zonder prothese, gaf $15,7 \%$ aan zich af en toe te schamen voor het ontbreken van de testis. Daarnaast gaf 22,6\% aan de verwijderde testis te missen.

\section{Conclusie}

Onze data laten zien dat niet met alle patiënten de optie TP wordt besproken, hoewel een op de zeven patiënten zich schaamt voor de missende testis en een kwart de verwijderde testis mist. Driekwart van de patiënten met een TP is tevreden met het resultaat, $14 \%$ gaf aan ontevreden te zijn met de prothese vanwege het formaat, de textuur en het ongemak in het scrotum.

\section{Risicodrempeloptimalisatie van lymfeklier- betrokkenheid bij prostaatkankerpatiënten voor het uitvoeren van pelviene lymfeklierdissectie: een kosteneffectiviteitsanalyse}

T.A. Hueting, E.B. Cornel, R.A. Korthorst, R.G. Pleijhuis, J.A.M. van der Palen en H. Koffijberg

Evidencio, Haaksbergen; Ziekenhuisgroep Twente, Almelo/ Hengelo; Medisch Spectrum Twente, Enschede; Universiteit Twente, Enschede

\section{Introductie}

Internationale richtlijnen raden het uitvoeren van de pelviene lymfeklierdissectie (PLND) af bij patiënten met een laag risico op lymfeklierbetrokkenheid. Risico's worden berekend met behulp van verschillende predictiemodellen. De Nederlandse richtlijn beveelt een risicodrempel van $10 \%$ aan, waar de Europese richtlijn een drempel van 5\% adviseert. Het doel van deze studie is de kosteneffectiviteit van de risicodrempels te kwantificeren en de optimale risicodrempel te identificeren.

\section{Materiaal en methode}

De verschillende afkapwaarden $(2 \%, 5 \%, 10 \%$ en $20 \%)$ die in de praktijk worden gebruikt om te bepalen of een patiënt in aanmerking komt voor een PLND, zijn met elkaar vergeleken in een beslisboom. De patiëntkarakteristieken in het hypothetische cohort zijn gebaseerd op een Nederlands patiëntencohort bestaande uit 934 patiënten die een extended PLND hebben ondergaan. De risico's op uitzaaiing zijn berekend met het Briganti-nomogram uit 2012. De strategieën zijn met elkaar vergeleken door middel van de incrementele kosteneffectiviteitsratio. Hierbij wordt het verschil in kosten gedeeld door het verschil in quality adjusted life years (QALYs). De maximale meerkosten van $€ 20.000$,- per QALY zijn toegepast voor het selecteren van de optimale strategie. Een Monte Carlo-simulatie is gebruikt als sensitiviteitsanalyse om de onzekerheid in het model te evalueren. De strategieën zijn vergeleken met de 20\%-afkapwaarde als referentie. 


\section{Resultaten}

Bij vergelijking van de vier geanalyseerde risicodrempels, liet de hoogste drempel (20\%) de laagste uitkomsten zien over tien jaar $(6,92$ QALYs en $€ 9.129,-)$. De laagste drempel $(2 \%)$ liet hierbij de hoogste uitkomsten zien $(7,02$ QALYs en $€ 10.949,-)$. De kansen voor de 2\%-, 5\%-, 10\%en $20 \%$-risicodrempels om kosteneffectief te zijn bij het toepassen van de maximale meerkosten van $€ 20.000$,- per QALY, waren respectievelijk 18\%, 38\%, 29\% en $16 \%$.

\section{Conclusie}

Het toepassen van de 5\%-risicodrempel voor het uitvoeren van de PLND op basis van de voorspelde kans op lymfeklieruitzaaiingen met het Briganti-nomogram uit 2012, geeft de beste uitkomsten vanuit een kosteneffectiviteitsperspectief.

\section{Allium ${ }^{\circledR}$-stent voor ureterobstructie: eerste ervaringen in vier Nederlandse klinieken}

M.T.W.T. Lock, E.A.E. Francisca, S. Roemeling, E.J. van Gennep en H.M.K. van Breda

Universitair Medisch Centrum Utrecht, Utrecht

\section{Introductie}

Ureterstricturen leiden tot ernstig nierfunctieverlies indien ze niet tijdig worden gediagnosticeerd en behandeld. Ondanks toenemend gebruik van minimaal-invasieve (laparoscopische) technieken lijkt de frequentie van ureterobstructies toe te nemen. Endo-urologische behandeling middels permanente stents heeft in het verleden problemen veroorzaakt door onder andere migratie, mucosa-ingroei, incrustatie en stentobstructie. Regelmatige JJ- en nefrostomiewissels worden door veel patiënten echter als invaliderend ervaren.

\section{Materiaal en methoden}

De nieuw ontwikkelde ureterstent is gemaakt van nikkeltitanium en vanbinnen bedekt met een biochemische copolymeer, die mucosa-ingroei en incrustatie tegengaat. De stent wordt op een katheter ingebracht in opgevouwen toestand (Ch10). Zodra de stent op de juiste plaats is gebracht (na ballondilatatie van de stenose) wordt een hoesje verwijderd, waardoor de stent zelf expandeert. Bij 14 patiënten ( 8 vrouwen, 6 mannen) werden 16 stents geplaatst. De leeftijd varieerde van 23-78 (gem. 62) jaar. Gepoogd wordt om de gebruikers van deze stent systematisch te vervolgen, zodat op termijn een goed functionerende database voorhanden is ten behoeve van nadere analyses.

\section{Resultaten}

De follow-up bedroeg 2-16 (gem. 6,5) maanden. 14 stents zijn in situ en goed doorgankelijk en zonder incrustaties. Strictuurlengte varieerde van 3-10 (gem. 5) cm. Een stent werd, na 6,5 maanden goed gefunctioneerd te hebben, in het stomazakje aangetroffen toen een $4 \mathrm{~cm}$ lange ureterBrickerstenose werd verwijderd. Een stent werd zonder problemen verwijderd wegens obstructie door een andere ingreep in de nabijheid van de stent. Alle patiënten die eerder een JJ (met wissels) hadden, gaven aan de stent superieur te vinden. Geen specifieke pijnklachten van de stents werden waargenomen.

\section{Conclusies}

De Allium ${ }^{\circledR}$-stent lijkt een aantrekkelijk alternatief voor JJen/of nefrostomiewissels. De stent voorkomt intraluminale groei en kan atraumatisch verwijderd worden. Vooral antegraad kan de stent geplaatst worden zonder anesthesie, zodat complexe patiënten (ASA 3+4, niet-toegankelijke buik) ook geholpen kunnen worden. Mogelijke nadelen zijn migratie, incrustatie en prijs van de stent.

\section{Aangepaste antibioticaprofylaxe bij het nemen van prostaatbiopten}

C.A.M. van Herpen, E.L. Koldewijn en M.C.A. Wegdam-Blans

Maastricht Universitair Medisch Centrum MUMC+, Maastricht; Catharina Ziekenhuis, Eindhoven; Laboratorium Medische

Microbiologie van PAMM, Veldhoven

\section{Introductie}

$\mathrm{Na}$ het nemen van prostaatbiopten ontwikkelt $0,6-4,1 \%$ van de patiënten een infectieuze complicatie. In de micro-organismen die dan worden gekweekt wordt vaak ciproxinresistentie gemeten. Ciproxin is op dit moment middel van eerste keuze als profylaxe voor het nemen van prostaatbiopten. Wij onderzochten of een aangepaste profylaxe minder infecties geeft.

\section{Materiaal en methoden}

Uit analyse van regionale resistentiepatronen van de 10 meest voorkomende uropathogenen (91\%) in $2011 \mathrm{t} / \mathrm{m}$ 2014 , kwam naar voren dat voor de combinatie ciproxin en fosfomycine $88 \%$ gevoelig werd gemeten. Fosfomycine is gemakkelijk toe te dienen en heeft een goede weefselbeschikbaarheid. Op basis hiervan werd vanaf 1 mei 2016 fosfomycine $3 \mathrm{~g}$ eenmalig aan de bestaande profylaxe van ciproxin $500 \mathrm{mg}$ eenmalig toegevoegd. Patiënten vanaf mei 2016 tot en met juli 2017 met combinatieprofylaxe werden vergeleken met een controlegroep (januari 2012 tot mei 2016), die eenmalig ciproxin $500 \mathrm{mg} 1$ uur voor de biopten kregen. Een powerberekening liet zien dat we minimaal 
214 patiënten dienden te includeren in de groep met combinatieprofylaxe om verschil aan te kunnen tonen $(\alpha=0,05$; power 0,8$)$. We gebruikten een ongecorrigeerde chi-kwadraattoets.

\section{Resultaten}

In de controlegroep werden 1559 biopten genomen. 56 patiënten $(3,6 \%)$ ontwikkelden een infectie, van wie 37 patiënten klinisch behandeld werden vanwege een urosepsis/ positieve bloedkweek $(2,4 \%) .19$ patiënten $(1,2 \%)$ hadden alleen een positieve urinekweek en werden poliklinisch behandeld. Van mei 2016 tot en met juli 2017 werden 268 patiënten gebiopteerd en kregen combinatieprofylaxe. 4 van de 268 patiënten $(1,5 \%)$ kregen een infectieuze complicatie waarvoor zij klinisch antibiotisch behandeld werden. Met de Fisher's exacttest bleek de $p$-waarde $0,0673(\mathrm{OR}=0,39$; $95 \%$-BI $=0,10-1,07)$.

\section{Conclusie}

De combinatie ciproxin en fosfomycine als profylaxe voorafgaand aan prostaatbiopten is niet beter dan alleen ciproxinprofylaxe. In de praktijk kan toevoegen van fosfomycine als profylaxe zinvol zijn bij vooraf bekende resistentie.

\section{Het gebruik van PET/CT-scans voor het stadiëren van bekkenklieren bij peniscarcinoom- patiënten met lieskliermetastasen}

\author{
S.R. Ottenhof, N.M. Graafland, R.S. Djajadiningrat, E. Vegt en \\ S. Horenblas \\ Antoni van Leeuwenhoek, Amsterdam
}

\section{Introductie}

Voor een adequate behandeling van lymfeklier-gemetastaseerd peniscarcinoom is goede stadiëring nodig. Liesklieren kunnen betrouwbaar (minimaal) invasief gestadieerd worden. Voor bekkenklieren ontbreekt echter nog betrouwbare beeldvorming. CT en MRI hebben onvoldoende sensitiviteit $(20-40 \%)$. Kleinere series beschreven goede resultaten van FDG-PET/CT-scans. In dit retrospectieve cohortonderzoek beschrijven we de testeigenschappen van FDG-PET/CTscans voor het stadiëren van bekkenklieren bij patiënten met lieskliermetastasen.

\section{Materiaal en methode}

Alle FDG-PET/CT-scans van patiënten met peniscarcinoom en lieskliermetastasen werden geanalyseerd. Indicatie voor PET/CT moest zijn: zeer verdacht lichamelijk onderzoek (cN2-cN3), positieve aspiratiecytologie of een positief excisiebiopt. De PET/CT-verslagen werden nagekeken. Als referentie gold een bekkenklierdissectie, andere of latere beeldvorming, of follow-up van minstens een jaar. Uit- slagen werden per zijde (rechts of links) en per patiënt geëvalueerd.

\section{Resultaten}

Scans van 90 patiënten werden geïncludeerd. Van 19 patiënten was geen referentie beschikbaar. Uiteindelijk werden van scans van 75 patiënten, 142 bekkenhelften geïncludeerd voor analyse. Referentie was bekkenklierdissectie in 48 bekkenhelften, (latere) beeldvorming in 52, en follow-up in 42 bekkenhelften. De resultaten zijn weergegeven in tabel 15.1. De sensitiviteit en specificiteit waren respectievelijk $81 \%$ en $88 \%$, positief en negatief voorspellende waarden waren respectievelijk $67 \%$ en $94 \%$. In een per-patiëntanalyse waren deze waarden vergelijkbaar (sensitiviteit en specificiteit beide $80 \%$, positief en negatief voorspellende waarden respectievelijk $67 \%$ en $89 \%$ ).

\section{Conclusies}

FDG-PET/CT heeft betrouwbare testeigenschappen voor het stadiëren van bekkenklieren van patiënten met peniscarcinoom en lieskliermetastasen.

Tabel 15.1 PET-uitslagen versus referentie per zijde.

\begin{tabular}{lll}
\hline & referentie positief & referentie negatief \\
\hline PET positief & 26 & 13 \\
\hline PET negatief & 6 & 95 \\
\hline
\end{tabular}

\section{Tien jaar expertise met aanpasbare continentietherapie voor postprostatectomie- urine-incontinentie: resultaten van ProACTTM-ballonnen bij 143 mannen}

T.C. Noordhoff, J.R. Scheepe en B.F.M. Blok

Erasmus Medisch Centrum, Rotterdam

\section{Introductie}

Postprostatectomie urine-incontinentie (PPI) is een invaliderende complicatie na een radicale prostatectomie. Een van de mogelijke behandelingen is de ProACT, waarbij para-urethraal twee ballonnen worden geplaatst. Poliklinisch kan het volume van de ballonnen via het slangetje in het scrotum worden aangepast. In deze studie analyseren we het padgebruik, de tevredenheid en de complicaties.

\section{Materiaal en methoden}

Tussen mei 2007 en augustus 2016 werd de ProACT bij 143 onbestraalde patiënten geïmplanteerd. Retrospectief werd gekeken naar het dagelijks padgebruik, de IPSS-score en de complicaties. Prospectief werd de patiënt gevraagd om een vragenlijst in te vullen over het dagelijks padgebruik en om de Patient Global Impression of Improvement (PGI-I) in te 
Tabel 16.1 Resultaten van ProACTTM-ballonnen bij 143 mannen.

\begin{tabular}{llll}
\hline & preoperatief & 6 maanden na implantatie & 1 jaar na implantatie \\
\hline pads/dag* & $n=143$ & $n=133$ & $n=95$ \\
$p$-waarde** & $3,5(2,0-5,0)$ & $1,0(0,0-2,0)$ & $0,0(0,0-2,0)$ \\
\hline postoperatieve uitkomst op incontinentie, $n(\%)$ & - & $<0,001$ & $<0,001$ \\
\hline succesvol & & $n=133$ & $n=95$ \\
$\geq 50-99 \%$ afname pads & & $63(47)$ & $48(51)$ \\
weinig/geen verbetering & & $34(26)$ & $26(27)$ \\
& $n=78$ & $36(27)$ & $n=65$ \\
\hline IPSS-totaal* & $8,5(4,8-14,0)$ & $n=107$ & $5,0(3,0-10,0)$ \\
$p$-waarde** & - & 0,38 & 0,08 \\
\hline & $n=81$ & $n=106$ & $n=66$ \\
\hline IPSS QOL* & $5,0(4,0-5,0)$ & $2,0(1,0-4,0)$ & $1,0(0,0-3,0)$ \\
$p$-waarde** & - & $<0,001$ & $<0,001$ \\
\hline
\end{tabular}

* mediaan (interquartile range).

** Wilcoxon signed rank test (verschil t.o.v. preoperatief).

vullen. De PGI-I-score geeft de door de patiënt ervaren postoperatieve verbetering/verslechtering weer. Het gebruik van geen pad of één dunne pad voor de zekerheid werd gedefinieerd als succesvol.

\section{Resultaten}

De mate van incontinentie preoperatief was mild (1-2 pads) bij 25\%, matig (3-4 pads) bij $40 \%$ en ernstig ( $\geq 5$ pads) bij $35 \%$ van de patiënten. De mediane leeftijd bij implantatie was 69 jaar. Er waren 17 (12\%) intraoperatieve perforaties van de urethra. Complicaties binnen 30 dagen volgens de Clavien-Dindoclassificatie: 8 (5,6\%) graad I, 3 (2,1\%) graad II, 3 (2,1\%) graad IIIb en 129 (90,2\%) patiënten hadden geen complicatie. Revisie werd bij 43 (30\%) patiënten verricht. Het padgebruik en de score op de IPSS QoL verbeterden significant (tabel 16.1). Na een mediane follow-up van 56 maanden vulden 112 patiënten de vragenlijst in. Bij 72 (64\%) patiënten verbeterde het padgebruik met $\geq 50-100 \%$. Succesvol was de behandeling bij 51 (46\%) patiënten. Het mediane padgebruik verbeterde van preoperatief 3,0 naar postoperatief 1,0 (67\% vermindering). De mediane PGI-I-score was 'veel beter' en 97 (87\%) patiënten ervoeren verbetering.

\section{Conclusies}

De minimaal invasieve ProACT-ballonnen hebben een duidelijke gunstige uitkomst op de continentie bij patiënten met PPI. Op de lange termijn is de meerderheid van de patiënten tevreden en is het gemiddelde padgebruik met $67 \%$ verbeterd.

\section{De ziekte van Peyronie: antifibrotische effecten van verteporfin op myofibroblasten}

\author{
D.C.J. Mohede, M.F. van Driel, I.J. de Jong en R.A. Bank
}

Universitair Medisch Centrum Groningen, Groningen

\section{Introductie}

Er is geen curatieve medicamenteuze behandeling voor de ziekte van Peyronie of fibrose in het algemeen. Verteporfin is geregistreerd voor de behandeling van maculadegeneratie en recente studies met fibroblasten afkomstig van de huid, longen en fibrotisch weefsel van morbus Dupuytren lieten een spectaculair inhiberende werking op expressie van fibrotische genen zien.

\section{Materiaal en methoden}

In het najaar van 2016 werd van vijf chirurgisch behandelde patiënten met de ziekte van Peyronie een biopt van het plaqueweefsel verkregen. Hieruit gekweekte fibroblasten werden gekenmerkt door de aanwezigheid van myofibroblasten middels immunokleuringen (phalloidine en alfa-smooth muscle actin) ter bevestiging van het pathologisch karakter. De cellen werden respectievelijk 24 en 48 uur blootgesteld aan verteporfin. Vervolgens werden messenger ribonucleïnezuur (mRNA) gehaltes van verschillende genen die betrokken zijn bij fibrose gemeten met polymerasekettingreacties en vergeleken met het YWHAZ-gen. Voor alle experimenten werd een controlegroep met slechts het oplosmiddel (dimethylsulfoxide) én een controlegroep zonder oplosmiddel genomen. 


\section{Resultaten}

Uit de immunokleuringen bleek dat in de plaques van alle patiënten myofibroblasten aanwezig waren. Door deze bevinding werd het pathologisch fibrotisch karakter van de gekweekte cellen bevestigd. De mRNA-ratio's van ACTA2, CCN2, COL1A1, COL5A1, EDA-FN, LOXL2, PLOD2 en SerpinH1 bleken na 24 én 48 uur behandelen significant lager in monsters van de met verteporfin behandelde cellen ten opzichte van de controlegroepen. Er waren geen verschillen tussen de twee controlegroepen. Expressie van YAP bleek niet te veranderen na behandeling met verteporfin.

\section{Conclusie}

Cellen die zijn opgekweekt uit plaqueweefsel van patiënten met de ziekte van Peyronie blijken myofibroblasten te bevatten, welke verantwoordelijk zijn voor pathologische fibrotische processen bij de ziekte van Peyronie. Verteporfin, een geregistreerd middel voor de behandeling van maculadegeneratie, heeft een significant inhiberende werking op genen die geassocieerd zijn met fibrose en is op termijn mogelijk te gebruiken voor de behandeling van de ziekte van Peyronie.

\section{Transurethrale en-bloc-hydrodissectie van niet-spierinvasieve blaastumoren}

\author{
M. Deelen en J.-V. Zambon \\ Zuyderland Medisch Centrum, Geleen
}

\section{Introductie}

Transurethrale resectie van blaastumoren is een veel gebruikte operatietechniek, waarbij blaastumoren gefragmenteerd worden verwijderd middels een diathermielis. Een alternatieve nieuwe techniek is een waterstraal ondersteunde en-blocresectie van niet-spierinvasieve blaastumoren, zogenoemde hydrodissectie. De Erbe HybridBlue ${ }^{\circledR}$ vult de submucosa onder de blaastumor met water, waarna met een hoogfrequentie-elektrode een en-blocresectie kan worden uitgevoerd met of zonder coagulatie. Een en-blocresectie is uit algemeen oncologisch oogpunt te prefereren boven een gefragmenteerde resectie.

\section{Materiaal en methoden}

Van november 2015 tot juni 2017 hebben in het Zuyderland Medisch Centrum Sittard-Geleen in totaal 35 patiënten een transurethrale hydrodissectie ondergaan van een of meer blaastumoren. Bij negen patiënten is de procedure uitgevoerd onder gelijktijdig gebruik van anticoagulantia.

\section{Resultaten}

Van de 35 patiënten was $80 \%$ man; de gemiddelde leeftijd bedroeg 74 jaar (range 41-83). Een en-blocresectie bleek mogelijk in 54\% van de gevallen. De gemiddelde operatietijd was 27 minuten (range 15-55), de gemiddelde opnameduur bedroeg twee dagen (range 2-5). Gelijktijdig gebruik van orale anticoagulantia gaf geen nabloedingen. In totaal was $54 \%$ van de preparaten pathologisch goed beoordeelbaar in afwezigheid van cauterisatieartefacten. Het gereseceerde materiaal betrof pT0-, pTa-, pT1- en pT2-urotheelcelcarcinoom in respectievelijk $34 \%, 46 \%, 3 \%$ en $3 \%$ van de gevallen. In $43 \%$ van het resectiemateriaal was musculus detrusor aanwezig. Na een en-blocresectie blijkt het en bloc verwijderen of uitspoelen soms technisch lastig te zijn.

\section{Conclusie}

Hydrodissectie is een innovatieve techniek, die de mogelijkheid biedt om en-blocresecties van niet-spierinvasieve blaastumoren uit te voeren. Meer ervaring dient te worden opgedaan met deze operatietechniek, waarbij met name de histologische beoordeelbaarheid moet worden verbeterd door reductie van cauterisatie-effecten. Een duidelijk voordeel is het feit dat deze en-blocresecties onder gelijktijdig gebruik van anticoagulantia kunnen worden uitgevoerd.

\section{Predictieve waarde van dual energy CT op de steencompositie}

\author{
N. Kerver, T. Korteweg en S. Roemeling \\ Universitair Medisch Centrum Groningen, Groningen
}

\section{Introductie}

Kennis van de steencompositie kan van invloed zijn op het behandelplan voor de steenpatiënt. DECT is een veelbelovende beeldvormende techniek voor het in vivo bepalen van de chemische compositie van urolithiasis. Het doel van dit onderzoek is om het onderscheidend vermogen van DECT op de chemische compositie van urolithiasis te bepalen.

\section{Materiaal en methoden}

Van juni 2016 tot april 2017 was van 37 patiënten een DECT en chemische steenanalyse beschikbaar. De composities van urolithiasis werden ingedeeld binnen categorieën composities (urinezuur, oxalaat en hydroxylapatiet) en binnen de groepen urinezuurstenen en niet-urinezuurstenen. Houndfield units (HU) en dual energy ratio (DE-ratio) werden vergeleken met respectievelijk een Kruskal-Wallis-toets (posthoc: Mann-Withney-toetsen met Bonferroni-correctie) en een Mann-Withney-toets. De primaire uitkomstmaat in dit onderzoek was het onderscheidend vermogen van DECT voor de verschillende steencomposities.

\section{Resultaten}

HU-waarden hadden een grote overlap in range voor de categorieën compositie. Daarentegen overlapte de ranges 
van de DE-ratio's in veel mindere mate. DE-ratio's waren significant verschillend tussen de categorieën composities $(p=0,00)$. Post-hocanalyses toonden aan dat de DE-ratio's significant verschilden tussen zowel urinezuur en oxalaat $(\mathrm{U}=5 ; \mathrm{r}=-0,53)$ alsmede tussen oxalaat en hydroxylapatiet $(\mathrm{U}=36 ; \mathrm{r}=-0,42)$ én tussen urinezuur en hydroxylapatiet $(\mathrm{U}=0 ; \mathrm{r}=-0,80)$. Tevens was de DE-ratio significant lager voor urinezuurstenen ten opzichte van niet-urinezuurstenen $(p=0,00)$. Urinezuurstenen konden met een sensitiviteit van $100 \%$ en een specificiteit van $94 \%$ gedifferentieerd worden van niet-urinezuurstenen.

\section{Conclusie}

DECT is in staat om te differentiëren tussen verschillende chemische composities van urolithiasis. Voor urinezuurstenen betreft dit een hoogsignificant en klinisch relevant resultaat. Voor de overige steencategorieën is aanvullende data-acquisitie nodig.

\section{Voorspellende factoren voor biochemisch recidief na robotgeassisteerde radicale prostatec- tomie: spelen ISUP-stadiëring en prostaatgrootte een rol?}

J.S. van Domburg, P.C. Weijerman, C.J. Wijburg, G.A.H.J. Smits en E.R.P. Collette

Ziekenhuis Rijnstate, Arnhem

\section{Introductie}

Een hogere kans op een biochemisch recidief (BCR) na een robotgeassisteerde radicale prostatectomie (RARP) kan gebruikt worden om het postoperatief beleid aan te passen. In deze analyse onderzoeken wij onder andere het prostaat- volume en de recent geïntroduceerde ISUP-scores als voorspellers van BCR.

\section{Materiaal en methode}

Tussen januari 2010 en december 2016 ondergingen 953 patiënten een RARP in ons centrum. Van 777 patiënten was voldoende follow-upinformatie bekend. Preoperatief PSA, pTumor-classificatie, pGleason-score, ISUP-score, positieve snijvlakken en prostaatgewicht werden geanalyseerd. Eindvariabele BCR is tweemaal PSA $>0,2 \mu \mathrm{g} / \mathrm{L}$.

\section{Resultaten}

De gemiddelde follow-up was 40 maanden. Bij 46,3\% van de patiënten was er sprake van een hoogrisicoprostaatcarcinoom ( $\geq$ pT3a en/of ISUP-score 3,4 of 5 ). BCR trad op bij $18 \%(140 / 777)$ van de patiënten. De gemiddelde tijd tot het optreden van BCR was 16,8 maanden ( $\mathrm{SD} \pm 18,9)$. Significante voorspellers voor BCR waren een iPSA $>25,00 \mu \mathrm{g} / \mathrm{L}$ en ISUP 3, 4 of 5. De kans op BCR was significant hoger in het pT3- dan in het pT2-stadium. Prostaatgewicht en een positief snijvlak bleken geen significante voorspellers van BCR te zijn.

\section{Conclusie}

Met een gemiddelde follow-up van 40 maanden had $82 \%$ van de 777 patiënten die een RARP ondergingen geen biochemisch recidief. Dit ondanks het feit dat de populatie uit $46 \%$ hoogrisicopatiënten bestond met $\geq$ pT3a en/of ISUP-score 3, 4 en 5. Risicofactoren voor BCR zijn preoperatief hoge PSA-waarden, ISUP-score 3 of hoger en pT3. Van belang is het significante verschil voor het risico op een recidief tussen de ISUP-score 2 en 3. Een positief snijvlak en het prostaatgewicht bleken in deze analyse geen onafhankelijke risicofactoren voor BCR te zijn. Zie tabel 20.1.

Tabel 20.1 Multivariabele Cox-regressieanalyse.

\begin{tabular}{llll}
\hline variabele & significantie & exp. (B) & 95\%-BI voor exp. (B) \\
\hline PSA preoperatief & $<0,001$ & 1,031 & $1,017-1,046$ \\
\hline ISUP 1 (pGl 6) referentie & & 1,507 & $0,768-2,961$ \\
\hline ISUP 2 (pGl 3+4) & 0,233 & 3,347 & $1,687-6,639$ \\
\hline ISUP 3 (pGl 4+3) & 0,001 & 7,213 & $3,718-13,995$ \\
\hline ISUP 4 (pGl 8) & $<0,001$ & 7,163 & $3,627-14,146$ \\
\hline ISUP 5 (pG1 9, 10) & $<0,001$ & & $2,439-5,657$ \\
\hline pT2abc referentie & & 3,714 & $0,988-1,005$ \\
\hline pT3ab & $<0,001$ & 0,996 & $0,849-1,804$
\end{tabular}




\section{Rol van transurethrale re-resectie (re-TUR) bij niet-spierinvasief blaascarcinoom}

S.L. Mekke en M.N.M. van der Aa

Spaarne Gasthuis, Hoofddorp

\section{Introductie}

De EAU-richtlijn beveelt een routinematige transurethrale re-resectie aan bij niet-spierinvasief blaascarcinoom als er sprake is van incomplete initiële TUR, bij Tx (geen detrusorweefsel in het biopt), bij T1-tumoren en bij graad-3-tumoren. De indicatie voor re-TUR verschuift door technologische innovatie en ontwikkeling van histologische definities. In deze studie wordt de kwaliteit van de behandeling in een perifeer centrum en de mogelijkheid tot verschuiving van de indicatie voor de re-TUR onderzocht.

\section{Methode}

Alle patiënten van het Spaarne Gasthuis (fusie van Spaarne Ziekenhuis en Kennemer Gasthuis in 2016), die in de jaren 2011 t/m 2016 gediagnosticeerd waren met primair nietspierinvasief blaascarcinoom met een indicatie voor re-TUR volgens de EAU-richtlijn, zijn verzameld en in een retrospectieve cohortstudie geëvalueerd $(n=199)$. Patiënten met primair en solitair carcinoma in situ zijn geëxcludeerd.

\section{Resultaten}

Een re-TUR werd uitgevoerd bij $46 \%$ van de patiënten (91/199). Bij 62\% (123/199) van de patiënten beschreef de patholoog detrusor in het initiële TUR-preparaat. Tijd tot eerste recidief was significant lager in de groep die een re-TUR onderging, 46\% recurrence free survival in 36 maanden versus $69 \%$ RFS in de groep die geen re-TUR onderging ( $p=0,01) .91$ patiënten ondergingen een re-TUR in verband met niet-radicale initiële TUR $(n=25)$, 32\% vanwege upstaging. In de groep re-TUR na radicale TUR-T werd in $38 \%$ van de gevallen resttumor gevonden, en in die groep 3,6\% upstaging.

\section{Conclusie}

Het oordeel radicaliteit van een operateur is onbetrouwbaar. De tijd tot recidief is langer in de groep waarbij, ondanks indicatie voor re-TUR, geen re-TUR is verricht. Tijd voor een aangescherpte indicatie.

\section{Perioperatieve beeldvorming met endosco- pische echografie en ex-vivo-MRI voor partiële bijnierresectie bij primair hyperaldosteronisme}

\author{
E.C.J. van de Wiel, R. Mann, A. Veltien, B. Küsters, J. Deinum en \\ J.F. Langenhuijsen \\ Radboud Universitair Medisch Centrum, Nijmegen
}

\section{Introductie}

Primair hyperaldosteronisme (PHA) wordt veroorzaakt door bilaterale bijnierhyperplasie of door een unilateraal aldosteronproducerend adenoom (APA). Vaak komt naast een APA ook multinodulaire hyperplasie $(\mathrm{MNH})$ in de bijnier voor. Een unilateraal APA wordt behandeld met een unilaterale laparoscopische totale adrenalectomie (LTA). Om bijnierweefsel te sparen, kan potentieel een solitair adenoom behandeld worden met partiële adrenalectomie. De preoperatieve CT-scan kan niet differentiëren tussen een solitair adenoom of bijkomende MNH. In deze studie is onderzocht of intraoperatieve endoscopische echografie (EUS) en postoperatieve ex-vivo-MRI kunnen differentiëren tussen deze subtypen en of deze beeldvorming in de toekomst kan helpen bij het uitvoeren van een partiële adrenalectomie.

\section{Materiaal en methoden}

15 patiënten met PHA op basis van een unilateraal adenoom op CT-scan, ondergingen een LTA. Intraoperatieve beeldvorming van de bijnier werd uitgevoerd met EUS. Postoperatieve beeldvorming van het specimen werd verkregen met behulp van een 11,7T-MRI. Echo- en ex-vivo-MRI-beelden werden vergeleken met de preoperatieve CT-scan en het histologisch rapport.

\section{Resultaten}

Bij alle 15 patiënten kon het APA gevisualiseerd worden met EUS. Op basis van EUS bestond bij acht van de 15 patiënten verdenking op bijkomende MNH. Vergeleken met de histologie klopte dit beeld bij zeven patiënten, één uitslag werd als drogbeeld beschouwd. Bij twee patiënten werd bijkomende MNH met EUS gemist. Met ex-vivo-MRI werd bij 14 van de 15 patiënten naast een adenoom een $\mathrm{MNH}$ gevonden. Vergeleken met de histologie komt dit neer op 18 extra micronoduli die alleen zijn gevonden met MRI.

\section{Conclusies}

EUS is een goede techniek om het adenoom intraoperatief te visualiseren en lijkt bruikbaar voor het uitvoeren van een partiële adrenalectomie. Ex-vivo-MRI is nieuw na adrenalectomie en zeer gevoelig voor het detecteren van micronoduli. Gebaseerd op deze resultaten lijkt de pathologie in sommige gevallen het aantal (micro)noduli te onderschatten. De exacte biochemische bijdrage van deze micronoduli bij PHA wordt momenteel verder onderzocht. 


\section{Drainage van geïnfecteerde lymfoceles na pelviene lymfeklierdissectie: een retrospectief overzicht met langdurige follow-up}

E. Bovelander, O.R. Brouwer, E.J. van Gennep, R.F.M. Bevers en K.T. Buddingh

Leids Universitair Medisch Centrum, Leiden

\section{Introductie}

Lymfoceles zijn een bekende complicatie van pelviene lymfeklierdissectie (PLKD), welke in geval van infectie gedraineerd dienen te worden. Onze indruk is dat deze patiënten zich vaak lang na de ingreep presenteren, terwijl veel registraties zich beperken tot de eerste 30 dagen. Het doel van deze studie is een overzicht te geven van geïnfecteerde lymfoceles die gedraineerd werden op korte of lange termijn na PLKD.

\section{Materiaal en methoden}

De dossiers werden onderzocht van alle patiënten die tussen 2004 en 2016 een laparoscopische PLKD ondergingen voor prostaatkanker, al dan niet in combinatie met radicale prostatectomie.

\section{Resultaten}

Een totaal aantal van 286 patiënten onderging een PLKD in de onderzochte periode. Bij 28 patiënten (10\%) was op enig moment drainage van een lymfocele noodzakelijk. Veertien patiënten (50\%) presenteerden zich binnen 30 dagen; het overige deel presenteerde zich verspreid tot anderhalf jaar na de operatie (figuur 23.1). De meerderheid van de patiënten $(67 \%)$ had bij presentatie koorts. Het gemiddelde leukocytengetal was $13 \pm 6 * 10^{9} / \mathrm{L}$ en het gemiddelde CRP bedroeg $168 \pm 115 \mathrm{mg} / \mathrm{L}$. De mediane duur van drainage bedroeg negen dagen (spreiding 0-28). Bij negen patiënten $(32 \%)$ waren multipele drainages noodzakelijk. Kweken van het drainvocht waren beschikbaar van 25 patiënten. Zes kweken toonden geen groei. In de overige kweken werd 21 keer Gram-positieve en vijf keer Gram-negatieve bacteriën gekweekt.

\section{Conclusie}

Geïnfecteerde lymfoceles presenteren zich in de helft van de gevallen pas langer dan 30 dagen na de lymfeklierdissectie. Een derde van deze patiënten heeft multipele drainages nodig. Studies die zich richten op preventie van lymfoceles dienen een langdurige follow-up in te bouwen.

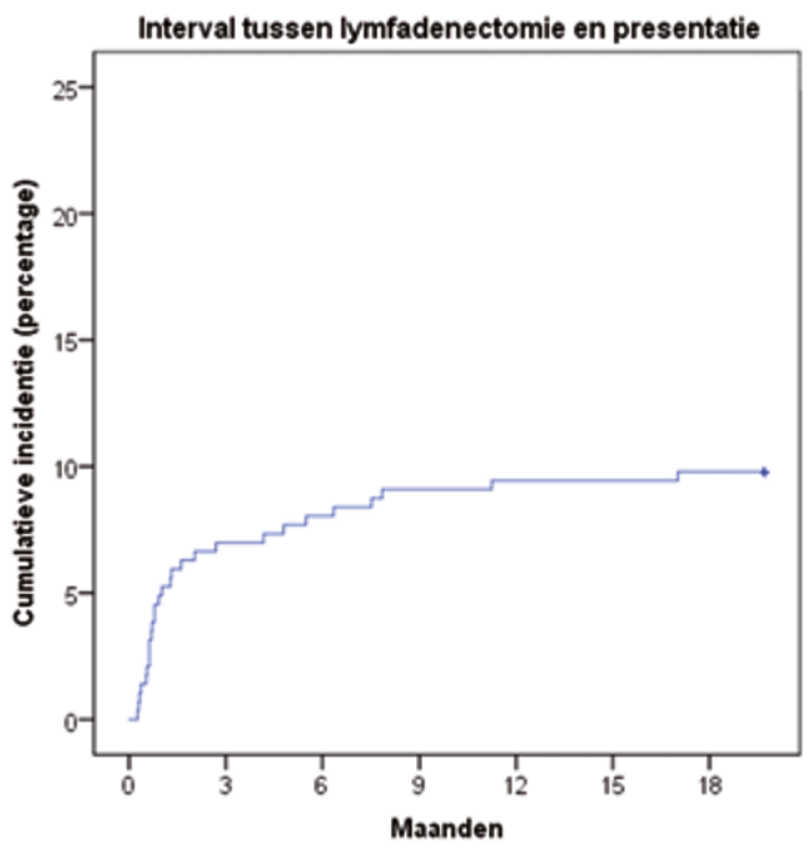

Figuur 23.1

\section{Robotprostatectomie stadiummigratie: uitkomsten van 3051 patiënten uit twee hoog- volumerobotcentra van de afgelopen negen jaar}

\author{
E.R.P. Collette, C.J. Wijburg, M. Gan, P.C. Weijerman, \\ G.A.H.J. Smits en S. Klaver \\ Rijnstate Ziekenhuis, Arnhem; Maasstad Ziekenhuis, Rotterdam
}

\section{Introductie}

De afgelopen jaren wordt voor laagrisicoprostaatkanker vaker active surveillance voorgesteld. Bij hoogrisicoprostaatkanker wordt de indicatie tot prostatectomie steeds meer aangegeven. Bij het diagnostisch proces wordt een MRIscan meer frequent gebruikt. Mogelijk is hierdoor de risicogroepverdeling veranderd; een patiënt die op dit moment een prostatectomie ondergaat, heeft mogelijk een prostaatcarcinoom met een hoger risicoprofiel dan voorheen. Doel van de studie is om deze stadiummigratie te bevestigen.

\section{Materiaal en methoden}

Retrospectieve analyse van twee deels prospectieve datasets. De ingrepen vonden plaats tussen januari 2009 en juli 2017. Pre-op risicostratificatie op basis van iPSA, cT en biopsie Gleason Grade Group (GGG); laag (GGG1; PSA < 10; cT1c-2a), middel (GGG2; PSA10-20; cT2b) en hoog (GGG 3, 4, 5; PSA > 20; cT3) risico. Post-op risicogroepen op basis van pT en GGG; laag (pT2abc en GGG 1, 2) of hoog (pT3ab en/of GGG 3, 4, 5) risico. 


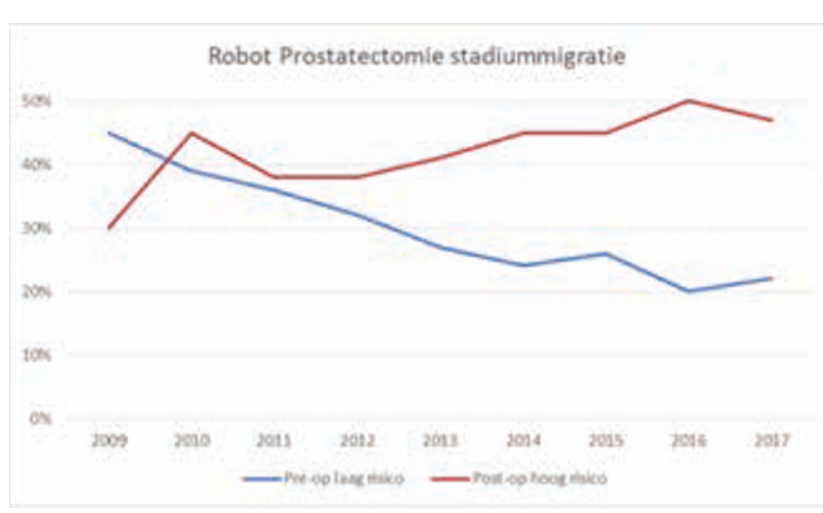

Figuur 24.1 Robotprostatectomie stadiummigratie.

\section{Resultaten}

In totaal ondergingen 3051 patiënten een robotgeassisteerde radicale prostatectomie (RARP) in twee Nederlandse hoogvolumecentra. Preoperatief gemiddeld PSA $11,7(0,6-170)$ en risicoverdeling als volgt: laag $29 \%$, middel $42 \%$ en hoog risico $29 \%$. Postoperatief laag risico $57 \%$ en hoog risico $43 \%$ van de patiënten. Zie figuur 24.1 voor stadiummigratie over de jaren. Wij zagen een significante daling van het aantal preoperatief laagrisicopatiënten ( $45 \%$ naar circa $20 \%)$ en een significante stijging van het aantal postoperatieve hoogrisicopatiënten (30\% naar circa 50\%). Preoperatief middel- of hoogrisicogroepen zijn significante voorspellers op een postoperatief hoogrisicoprostaatkanker $(p<0,01$ en HR 3,7 en 12,0$)$.

\section{Conclusie}

Deze analyse van 3051 patiënten uit twee hoogvolumecentra laat zien dat er een stadiummigratie is richting hoogrisicoprostaatkanker.

\section{De waarde van de Modified Frailty Index bij spierinvasief blaascarcinoom}

M.J.H. Voskamp, M. Vermeer, G.J. Molijn en E.B. Cornel

Ziekenhuis Groep Twente, Almelo

\section{Introductie}

In 2016 werden in Nederland 962 cystectomieën voor spierinvasief blaascarcinoom uitgevoerd. Ter vermindering van postoperatieve complicaties zou chemoradiatie een goed alternatief kunnen zijn. Om een keuze te kunnen maken tussen deze twee therapieën, worden op dit moment de leeftijd, ASA en Charlson Comorbidity Index (CCI) gebruikt. In de praktijk blijken deze echter niet altijd voorspellend te zijn. Studies bij verschillende maligniteiten hebben aangetoond dat de modified Frailty Index (mFI) van nut kan zijn bij de identificatie van high-riskpatiënten. Doel van dit onderzoek is om, op basis van deze index, patiënten te identificeren die
Tabel 25.1 Patiëntkarakteristieken $(n=100)$.

\begin{tabular}{ll}
\hline mannen $n(\%)$ & $74(74 \%)$ \\
\hline leeftijd: mean $( \pm \mathrm{SD})$ & $69( \pm 8,4)$ \\
\hline ingreep & $92(92 \%)$ \\
\hline urinedeviatie $n(\%)$ & $13(6)$ \\
\hline opnameduur in dagen: median (IQR) & $225( \pm 60)$ \\
\hline OK-duur in min: mean $( \pm \mathrm{SD})$ & $450(450)$ \\
\hline bloedverlies in ml: median $(\mathrm{IQR})$ & $37(37 \%)$ \\
\hline risicoscores: $n(\%)$ & $27(27 \%)$ \\
\hline mFI 0 & $20(20 \%)$ \\
\hline mFI 1 & $16(16 \%)$ \\
\hline mFI 2 & $75(75 \%)$ \\
\hline mFI $\geq 3$ & $25(25 \%)$ \\
\hline ASA 1-2 & $69(69 \%)$ \\
\hline complicaties $3-4$ & $31(31 \%)$ \\
\hline Clavien-Dindo $1-5: n$ &
\end{tabular}

een grotere kans hebben op een ernstige complicatie na cystectomie. Hiermee zou de voorlichting en behandeling voor de patiënt verder gepersonaliseerd kunnen worden.

\section{Materiaal en methoden}

Alle patiënten die een cystectomie hebben ondergaan met aanleg van een urinedeviatie of neoblaas met nadien een fast track voedingsprotocol, werden geïncludeerd. Retrospectief werd de $\mathrm{mFI}$ gescoord. Deze index bestaat uit 11 punten die zijn gebaseerd op patiëntkarakteristieken en is een afgeleide van de Canadian Study of Health and Aging Frailty Index die uit 70 punten bestaat. Tevens werden leeftijd, ASA en CCI genoteerd. Complicaties werden geregistreerd als Clavien Dindo (CD) 1-5.

\section{Resultaten}

Tussen 2012 en 2017 werden 100 cystectomieën in onze kliniek uitgevoerd. De gemiddelde ( \pm SD) leeftijd was 69 $( \pm 8,4)$ jaar. Zie voor overige karakteristieken tabel 25.1. Bij 69 patiënten trad binnen 90 dagen postoperatief een complicatie op, waarvan 31 een $\mathrm{CD} \geq 3$ hadden. Patiënten met een $\mathrm{CD} \geq 3$ hadden een significant hogere $\mathrm{mFI}$ dan patiënten met een $\mathrm{CD}<3(p=0,008)$. De mediane (IQR) $\mathrm{mFI}$ bij $\mathrm{CD}$ $<3$ was $1(0-2)$ en bij $\mathrm{CD} \geq 3$ was deze 1 (1-3). Odds ratio $1,5(95 \%-\mathrm{BI}=1,1-2,1 ; p=0,009)$. Er werd geen correlatie gevonden tussen leeftijd, ASA, CCI en $\mathrm{CD} \geq 3$.

\section{Conclusie}

In onze serie patiënten is er een relatie tussen de $\mathrm{mFI}$ en ernstige complicaties. Het is daarom te overwegen om bij patiënten met spierinvasief urotheelcelcarcinoom de $\mathrm{mFI}$ te gebruiken bij de voorlichting van de behandelmogelijkheden. 


\section{Radiotherapie bij ouderen (80-plus) met spierinvasief blaascarcinoom: klinische resultaten van plan-of-the-day geïntegreerde boosttechniek gecombineerd met lipiodolmarkering}

\author{
A.J.W Beulens, G.J. Meijer, M. de Wildt, P.P. van der Toorn en \\ W.A. Scheepens \\ Catharina Ziekenhuis, Eindhoven
}

\section{Introductie}

De curatieve opties voor patiënten met spierinvasief blaascarcinoom (SIBC) zijn chirurgische behandeling of radiotherapie, al dan niet met chemotherapie. Bij de oudere patiënt (i.e. 80-plus) is de keuze voor een chirurgische interventie minder aantrekkelijk, gezien de impact van de operatie op de vaak al relatief fragiele patiënt. Bij conventionele radiotherapie wordt de gehele blaas met een marge van 2-3 cm rondom de blaas bestraald om een curatieve dosis te kunnen garanderen. In deze studie wordt, vier tot acht weken na een complete transurethrale resectie, de tumorsite onder doorlichting gemarkeerd door middel van lipiodol (gejodeerde papaverolie) markeringen. Een week na de markering worden meerdere CT-scans gemaakt bij verschillende blaasvullingen. Op basis van de CT-scans kunnen zes bestralingsplannen gemaakt worden. Tijdens de bestraling kan, na het maken van een conebeam-CT, op basis van de blaasvulling, dagelijks het best passende bestralingsplan plan-of-the-day geselecteerd worden, waardoor een betere targeting van de tumorsite gerealiseerd kan worden. Dit resulteert in de mogelijkheid om gericht met hogere dosis de tumor te bestralen, terwijl tegelijkertijd een lagere dosis op de rest van de blaas en de omliggende weefsels wordt gegeven.

\section{Materialen en methoden}

44 patiënten met T2-T4N0M0 graad 2-3 SIBC werden volgens het in de introductie beschreven protocol bestraald. Drie maanden na de radiotherapie werd door middel van cystoscopie de respons beoordeeld. Follow-up werd zesmaandelijks verricht door middel van cystoscopie, cytologie en beeldvorming.

\section{Resultaten}

Van de 44 behandelde patiënten bleek gedurende de followup (mediaan 50 maanden) bij 11 patiënten (25\%) toch sprake te zijn van gemetastaseerde ziekte. Vier patiënten (9\%) lieten een lokaal recidief zien (veelal pTa-letsels). Er overleden 23 patiënten (52\%), van wie $9(39 \%)$ ten gevolge van urotheelcelcarcinoom. De overall survival na drie jaar was $49 \%$, de mediane survival was 35 maanden.

\section{Conclusie}

Curatieve radiotherapie door middel van lipiodolmarkering en plan-of-the-day kan een eerstekeusbehandeling zijn bij de oudere patiënt (i.e. 80-plussers) met SIBC.

\section{Precisiediagnostiek voor prostaatkanker middels transperineale MRI-TRUS-fusiebiopsie (T-MTFB) onder lokale verdoving}

\author{
J.J. Immerzeel en F.M.J. Debruyne \\ Andros Mannenkliniek, Arnhem
}

\section{Introductie}

Wij presenteren de uitkomsten van een (prospectieve) registratiestudie waarbij routinematig na mp-MRI onder lokale verdoving transperineale MRI-TRUS-fusiebiopsie (T-MTFB) wordt verricht.

\section{Materiaal en methode}

Van december 2015 tot juli 2017 werd bij 994 mannen met klinische of biochemische verdenking op prostaatkanker na klinisch en echografisch (TRUS) onderzoek standaard een mp-MRI vervaardigd. Bij verdenking op prostaatkanker werd aansluitend een T-MTFB verricht.

\section{Resultaten}

Bij 41,5\% (413/994) mannen werden biopten genomen, 382 met verdachte MRI (PIRADS 3-5) en 31 met PIRADS 1-2, maar verdenking op prostaatkanker bij DRE, PSA-kinetiek, selectMDX-test of naar aanleiding van familiaire belasting. De standaard T-MTFB-procedure bestond bij 352 mannen uit targeted biopten plus random biopten. Bij 61 patiënten werden alléén targeted biopten genomen, meestal na voorafgaande negatieve TRUS-randombiopten, een zeer uitgebreid proces of $\mathrm{M}+$. Prostaatkanker werd in 75,3\% (311/413) van de gevallen vastgesteld bij patiënten met één PIRAD-35-bevinding. Indien er meerdere MRI-laesies waren, steeg dit naar 77,5\%. Bij 214 patiënten (68,8\%) was er sprake van een klinisch significant resultaat (Gleason-score $\geq 7$ ). Antibiotische profylaxe werd niet toegepast. Er kwamen geen post-biopsie-infecties voor. Bij alle mannen werd de pijnscore van de procedure geëvalueerd met de Visueel Analoge Schaal (VAS) van 0-10. De gemiddelde score voor de anesthesie was 2,17 en 1,19 voor de biopten zelf. Zie tabel 27.1.

\section{Conclusie}

Het verrichten van mp-MRI gevolgd door T-MTFB levert een hoger detectiepercentage van klinisch significante prostaatkanker dan de gebruikelijke random TRUS-biopten. Met de prebiopsie-MRI kan $>50 \%$ onnodige biopten worden voorkomen. De T-MTFB onder lokale verdoving wordt zeer goed verdragen en is complicatievrij. Deze benadering zou dan ook standaard kunnen of moeten worden in de dagelijkse urologische praktijk. 
Tabel 27.1 Pathologiebevindingen van de biopten $(n=413)$ van dominante laesies.

\begin{tabular}{|c|c|c|c|c|c|c|}
\hline$n$ & & benigne & GS $3+3$ & GS $3+4$ & GS 4+3 & $\mathrm{GS}>4+3$ \\
\hline 31 & PIRADS 2 & 20 & 9 & 1 & 1 & 0 \\
\hline $8 \%$ & & $65 \%$ & $29 \%$ & $3 \%$ & $3 \%$ & $0 \%$ \\
\hline 38 & PIRADS 3 & 25 & 8 & 3 & 2 & 0 \\
\hline $9 \%$ & & $66 \%$ & $21 \%$ & $8 \%$ & $5 \%$ & $0 \%$ \\
\hline 175 & PIRADS 4 & 46 & 54 & 44 & 21 & 10 \\
\hline $42 \%$ & & $26 \%$ & $31 \%$ & $25 \%$ & $12 \%$ & $6 \%$ \\
\hline 169 & PIRADS 5 & 11 & 26 & 56 & 22 & 54 \\
\hline $41 \%$ & & $7 \%$ & $15 \%$ & $33 \%$ & $13 \%$ & $32 \%$ \\
\hline \multirow[t]{2}{*}{413} & totaal & 102 & 97 & 104 & 46 & 64 \\
\hline & & $25 \%$ & $23 \%$ & $25 \%$ & $11 \%$ & $15 \%$ \\
\hline
\end{tabular}

MRI-bevindingen (PIRADS 2-5) vs. Gleason-score (GS).

\section{MRI-echo fusiegeleide prostaatbiopten versus systematische prostaatbiopten in bioptnaïeve mannen}

M. Gayet, A. van der Aa, H.P. Beerlage, B.Ph. Schrier, M. Gielens, G.J. Jager, P.F.A. Mulders en H. Wijkstra Jeroen Bosch Ziekenhuis, 's- Hertogenbosch; Radboud Universitair Medisch Centrum Nijmegen; Technische Universiteit, Eindhoven

\section{Introductie}

In de literatuur wordt een verhoogde detectie van hooggradige prostaatcarcinomen gerapporteerd bij gebruik van MRI-echo fusiegeleide prostaatbiopten vergeleken met gebruik van systematische TRUS-geleide biopten, met name bij mannen na negatieve TRUS-geleide biopten en in hoogvolumecentra. In deze studie werden detectie van prostaatcarcinoom en pathologie-uitslagen vergeleken tussen MRI-echo-fusiegeleide biopten (TB) en systematische TRUS-geleide biopten (SB) bij bioptnaïeve patiënten in ons centrum.

\section{Materiaal en methoden}

In deze in-patient control study ondergingen 82 bioptnaïeve mannelijke patiënten met een PSA tussen de $4 \mu \mathrm{g} / \mathrm{L}$ en
$30 \mu \mathrm{g} / \mathrm{L}$ zowel SB als TB in dezelfde sessie, waarbij ge-

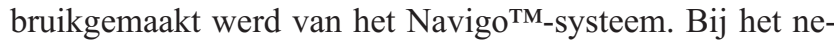
men van de SB was de operateur geblindeerd voor zowel de MRI-beelden als de uitslag.

\section{Resultaten}

Met SB en TB gecombineerd werd prostaatcarcinoom gedetecteerd bij $54,9 \%$ van de patiënten. Significant prostaatcarcinoom (Gleason-score $\geq 3+4=7$ ) werd gedetecteerd bij $35,4 \%$ van de patiënten. Met SB werd bij 48,8\% van de patiënten prostaatcarcinoom en bij $32,9 \%$ van de patiënten significant prostaatcarcinoom gedetecteerd. Met TB was dit $35,4 \%$ en $23,2 \%$. Klinisch significante upgrading (van benigne naar prostaatcarcinoom of van insignificant naar significant prostaatcarcinoom) vond plaats in $6,1 \%$ van de gevallen wanneer TB aan SB werd toegevoegd en in $24,4 \%$ van de gevallen wanneer SB aan TB werd toegevoegd. Zie tabel 28.1.

\section{Conclusie}

In onze onderzoekspopulatie worden zowel bij het gebruik van alleen SB als van alleen TB significante prostaatcarcinomen gemist. Bij het gebruik van MRI-echo fusiegeleiding lijkt het achterwege laten van SB niet gerechtvaardigd en derhalve wordt een combinatie van SB en TB aanbevolen.

Tabel 28.1 Vergelijking van uitkomsten per patiënt van SB en TB.

\begin{tabular}{lllll}
\hline & systematische biopten & & \\
\hline targeted biopten & benigne & insignificant PCa & significant PCa & totaal \\
\hline niet verricht & 15 & 6 & 3 & 24 \\
\hline benigne & 22 & 3 & 4 & 29 \\
\hline insignificant PCa & $\mathbf{2}$ & 4 & 4 & 10 \\
\hline significant PCa & $\mathbf{3}$ & 0 & 16 & 19 \\
\hline totaal & 42 & 13 & 27 & 82 \\
\hline
\end{tabular}

Cursief $=$ patiënten met een klinisch-significante pathologie-upgrade met systematische biopten. Bold $=$ patiënten met een klinisch-significante pathologie-upgrade met targeted biopten. 


\section{De toegevoegde waarde van MRI-prostaat in de diagnostiek}

M.A. van der Slot, M.O. Boerma, K. Koster, A. van Gorp, S.E.M. Kolderman en T. Wolters

Deventer Ziekenhuis, Deventer

\section{Introductie}

De waarde van mpMRI bij aanhoudende verdenking op prostaatkanker na negatieve prostaatbiopten staat vast. Er is echter veel minder bekend over de rol van mpMRI als initiële diagnostiek. In deze studie onderzochten we de toegevoegde waarde van mpMRI voorafgaand aan initiële prostaatbiopten.

\section{Materiaal en methoden}

Tussen 1 juni 2016 en 31 mei 2017 werd bij 96 mannen met verdenking op prostaatkanker zonder eerdere biopten een mpMRI voorafgaand aan biopten gemaakt. Er werden standaardbiopten (8-12) verricht uit de perifere zone en aanvullende targeted biopten (cognitieve fusie) in geval van een PIRADS 3-, 4- of 5-laesie op mpMRI. Toegevoegde waarde van de MRI werd gedefinieerd als prostaatkankerdiagnoses die werden gemist in de standaardbiopten of het vinden van een hogere Gleason-score in de targeted biopten, waarbij significant prostaatkanker werd gedefinieerd als Gleasonscore $3+4$ of hoger. Het betreft een retrospectief onderzoek.

\section{Resultaten}

Bij 67 van de 96 patiënten $(69,8 \%)$ werd prostaatkanker vastgesteld in de biopten, waarvan $50(52,1 \%)$ een significante tumor betrof. Bij vijf (5,2\%) patiënten werd de tumor alleen vastgesteld op basis van de targeted biopten, waarbij het bij drie patiënten een significante tumor betrof. Bij de 14 negatieve mpMRI's werd bij vier $(28,6 \%)$ patiënten alsnog prostaatkanker gevonden, waarvan drie tumoren significant waren. Bij twee patiënten was de Gleason-score in de targeted biopten hoger dan in de standaardbiopten, beide gingen van Gleason-3+3 naar $-3+4$.

\section{Conclusies}

Bij slechts 7 van de 96 (7,3\%) patiënten had het verrichten van een MRI-scan voorafgaand aan de biopten (mogelijk) klinische consequenties door het diagnosticeren van prostaatcarcinoom dat niet in de randombiopten aanwezig was of een hogere Gleason-score had in de targeted biopten. Daarnaast werd bij 14 niet-afwijkende MRI's bij drie patiënten significant prostaatkanker gediagnosticeerd. In deze studie lijkt de MRI voorafgaand aan de initiële biopten een beperkte toegevoegde waarde te hebben. 